Review of Palaeobotany and Palynology, 21(1976): 5-23

๑ Elsevier Scientific Publishing Company, Amsterdam - Printed in The Netherlands

\title{
CURRENT STATUS OF THE PROGYMNOSPERMOPSIDA
}

\author{
CHARLES B. BECK
}

Department of Botany, University of Michigan, Ann Arbor, Mich. (U.S.A.)

(Accepted for publication February 11, 1975)

\section{ABSTRACT}

Beck, C. B., 1976. Current status of the Progymnospermopsida. Rev. Palaeobot. Palynol., 21:5-23.

The three progymnosperm orders, Aneurophytales, Protopityales, and Archaeopteridales, are characterized and analyzed. The possibility that some of the apparent taxonomic diversity of the Aneurophy tales and Archaeopteridales might reflect developmental variation is considered as well as the probability that much of it reflects evolutionary change. A detailed discussion of the phylogenetic position of the Progymnospermopsida concludes the paper.

\section{INTRODUCTION}

Establishment of the Progymnospermopsida followed the discovery of Archaeopteris lateral branch systems attached to stems of Callixylon structure (Beck, 1960a, b).

The group is comprised of plants of gymnospermous anatomy and freesporing, homosporous or heterosporous reproduction. Plants of some genera attained the stature of large trees (Beck, 1962a, 1964), and produced secondary vascular tissues and periderm. Branching in lateral branch systems is three-dimensional in many forms, but occurs in one plane in some Upper Devonian and Lower Mississippian genera (e.g., Archaeopteris, Siderella). Ultimate appendages (leaves) may be laminate or finely divided, and when of the latter type may be either three-dimensional or flattened (see Scheckler and Banks, 1971b).

Three orders have been recognized: Aneurophytales (Kräusel and Weyland, 1941), Protopityales (Walton, 1957), and Archaeopteridales (Arnold, 1930).

\section{ANEUROPHYTALES}

The order is characterized predominantly by three-dimensional branching. Branching patterns of vegetative branch systems are either helical (Rellimia [formerly Protopteridium], Aneurophyton, Triloboxylon, Cairoa) or 
decussate (Tetraxylopteris) or in one plane (Triloboxylon, Proteokalon). The ultimate appendages are arranged helically in Rellimia, Aneurophyton, and Triloboxylon, and decussately in Tetraxylopteris. In Proteokalon an adaxial pair alternates with a single abaxial ultimate appendage (Scheckler and Banks, 1971b). The arrangement of ultimate appendages in Cairoa is unclear.

Sporangia are borne terminally, and in several genera (Tetraxylopteris [Bonamo and Banks, 1967], Rellimia [Leclercq and Bonamo, 1971, 1973], and Triloboxylon [Scheckler and Banks, 1972], on two-ranked (planated) lateral branch systems. Second order branching in the fertile systems of Rellimia and Tetraxylopteris is dichotomous, but sporangia are borne on terminal axes arranged in an irregularly pinnate manner (Bonamo and Banks, 1967; Leclercq and Bonamo, 1971).

Primary xylem forms a ribbed protostele except in ultimate appendages where it is a terete strand (Beck, 1957; Scheckler and Banks, 1971a). The secondary wood is pycnoxylic with generally tall, narrow rays that in some genera (Triloboxylon, Tetraxylopteris) contain some ray tracheids (Scheckler and Banks, 1971a). One species, Triloboxylon hallii, possesses secondary wood with tracheary pits arranged in radially banded groups like that of Callixylon (Archaeopteris) of the Archaeopteridales. Secondary xylem is unknown in Cairoa (Matten, 1973).

The secondary phloem, where known (Tetraxylopteris [Beck, 1957], Triloboxylon [Scheckler and Banks, 1971a], Proteokalon [Scheckler and Banks, 1971b] ), is characterized by abundant thick-walled fibers. Phloem rays vary in width from one to several rows of cells, and are usually dilated in comparison with their counterparts in the secondary xylem.

The outer cortex of all members of the Aneurophytales (with the possible exception of Aneurophyton in which it is unknown) is characterized by thick-walled sclerenchyma cells, often forming a network of longitudinally oriented, interconnected strands, the so-called dictyoxylon cortex of earlier authors (Beck, 1957; Matten and Banks, 1966; Leclercq and Bonamo, 1971; Scheckler and Banks, 1971a, b; Matten, 1973).

The Aneurophytales extend through the geologic column from lowermost Middle Devonian (early Eifelian) to middle Upper Devonian (late Frasnian). Ranges of individual genera are given in Fig.1.

Six genera are currently assigned to the order. These are: (1) Aneurophyton Kräusel et Weyland, 1923; see also Leclercq (1940); (2) Cairoa Matten, 1973, (3) Proteokalon Scheckler et Banks, 1971b; (4) Rellimia Leclercq et Bonamo, 1973; see also Leclercq and Bonamo (1971); (5) Tetraxylopteris Beck, 1957; see also Matten and Banks (1967); Bonamo and Banks (1967); Scheckler and Banks (1971a); (6) Triloboxylon Matten et Banks, 1966; see also Scheckler and Banks (1971a, 1972).

Another genus, Sphenoxylon, has been shown to represent poorly preserved, petrified stem axes of Tetraxylopteris (Matten and Banks, 1967; Scheckler and Banks, 1971a).

Stauroxylon Galtier, 1970 from the Lower Carboniferous of France is 


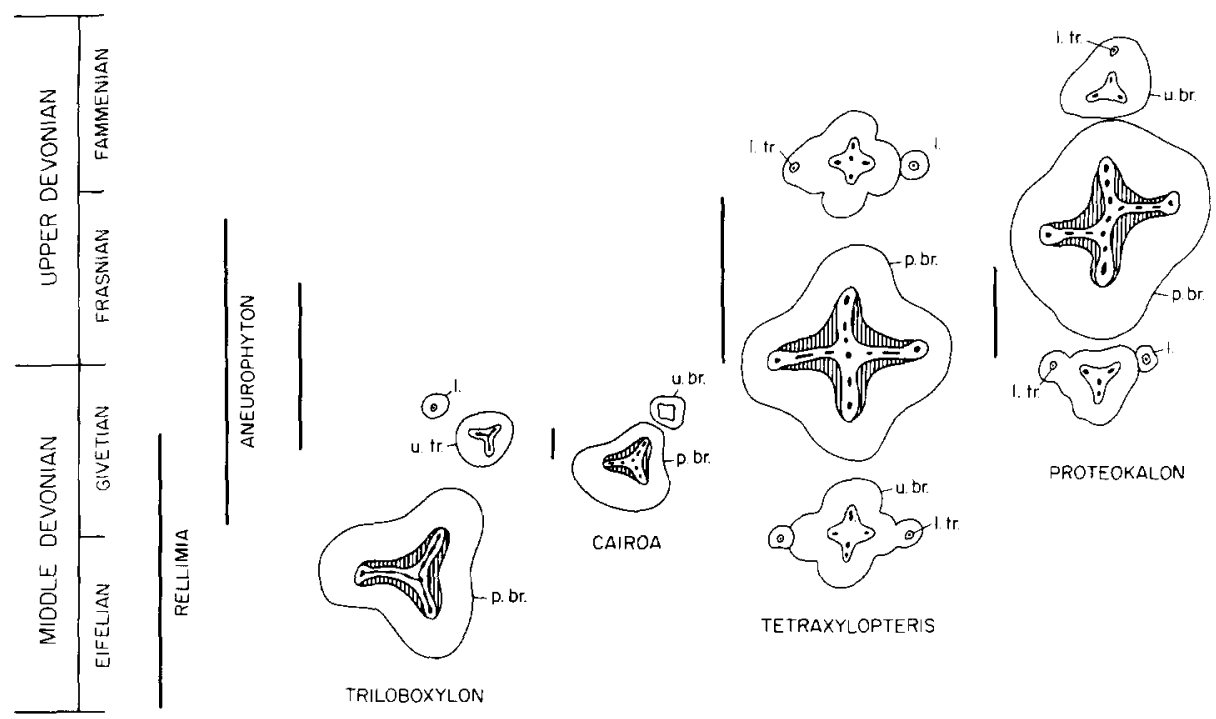

Fig.1. Geologic ranges (heavy lines to left of names and diagrams) and morphologic features of some members of the Aneurophytales. Some aspects of the primary and secondary xylem, branching patterns, and phyllotaxy are shown. Lined secondary xylem encloses unshaded metaxylem that contains black protoxylem strands. The smallest appendages containing traces, terete in sectional view, are considered to be the basal parts of leaves. Genera are arranged from left to right in order of increasing levels of morphologic specialization. $l=$ leaf; $l . t r .=$ leaf trace; $p . b r .=$ penultimate branch; u.br. = ultimate branch.

remarkably similar to Tetraxylopteris. It is characterized by decussate branching and a four-ribbed protostele. Parenchymatous protoxylem occurs in mesarch strands. Opposite to subopposite pairs of traces (terete in section), apparently the vascular supply to ultimate appendages, diverged from the irregularly shaped vascular column of the second-order branches. It is not clear whether ultimate appendages were two-ranked or decussately arranged. The vascular column of the second order branches (as seen in transverse view) elongated in the plane of trace divergence. Following the production of the first pair of traces, this column, at a higher level, became elongate at right angles to the region from which the first pair had diverged. Although a second pair of traces is not preserved in Galtier's specimen, this evidence supports the possibility of a decussate arrangement of ultimate appendages.

Although Galtier believes that Stauroxylon is probably an aneurophytalean progymnosperm, he hesitates to assign it definitely to this group because of several divergent characters, and because its fructifications are unknown. Primary among the differences he cites is the presence of scalariform pits in the secondary xylem. Because of poor preservation, however, the details of tracheary pitting are not clear. The pits may have been similar to the elliptical bordered pits of the inner secondary wood of Protopitys scotica. As Smith (1962) has shown, tracheids in later-formed secondary wood of 
this genus were circular-bordered. Whether or not this was true also of Stauroxylon must await the discovery of specimens with larger amounts of secondary xylem.

I agree with Galtier that Stauroxylon is almost certainly a member of the Aneurophytales. If subsequent study corroborates this view, this genus will become the first record of a Lower Carboniferous aneurophyte.

Childanophyton, from the Lower Mississippian of southwestern Virginia, recently established by Gensel (1973), and the Upper Devonian genus Rhacophyton, have been suggested as possible aneurophytes (for discussion of the taxonomic affinities of the latter genus, see Andrews and Phillips, 1968). Childanophyton is very similar in some features to Rhacophyton, and also to Protocephalopteris (see Schweitzer, 1968). Rhacophyton, is considered to be a coenopterid fern by Leclercq and Bonamo (1971) who base their conclusion on the presence of clepsydroid primary xylem strands with peripheral loops. The genus is also characterized by scalariform tracheids in the secondary xylem. Rhacophyton, Protocephalopteris, and Childanophyton may well be primitive members of the Zygopteridaceae (Coenopteridales).

Andrews et al. (1974) have described probable Middle Devonian specimens from Chaleur Bay, New Brunswick with aneurophytalean features. They assign a new name, Chaleuria, to this material. Whereas only two orders of branches are illustrated in their restoration (the second order bearing dichotomous sterile or fertile ultimate appendages), Andrews et al. (1974) describe some specimens as having three orders of branches. Chaleuria produced spores of variable size that fall into two intergrading size classes, considered by Andrews et al. (1974) to represent "incipient heterospory". Although I have not seen the specimens, the published descriptions and photographs seem to present many of the important characteristics of Aneurophyton as described by Kräusel and Weyland (1923, 1926, 1929), and as amplified and modified by Leclercq (1940), Streel (1964) and Potonié (1967). Andrews et al. (1974) compare Chaleuria with Arctophyton, a poorly understood plant from the early Middle Devonian of Spitsbergen which Schweitzer (1972) suggests might have been related to Aneurophyton. Both Chaleuria and Arctophyton are considered to be possible members of the Progymnospermopsida.

Further study of Chaleuria, Arctophyton, and Aneurophyton is required to clarify the status and relationships of these genera.

Two form genera, Eospermatopteris and Callixylon, include fossils that represent parts of several of the genera listed above. Eospermatopteris is the name for sandstone stump casts commonly thought to belong to Aneurophyton (Kräusel and Weyland, 1941). They might also belong to some other aneurophytes. Callixylon, the type of secondary wood with groups of circular bordered pits arranged in radial bands, is a feature of at least one aneurophyte, Triloboxylon hallii (Scheckler and Banks, 1971a), as well as of Archaeopteris and Eddya of the Archaeopteridales (Beck, 1960b, 1967). 


\section{PROTOPITYALES}

This order is represented by a single genus, Protopitys Göppert, of Lower Carboniferous age, recently studied by Walton $(1957,1969)$ and Smith (1962). The plant was probably pteridophytic in reproduction, and bore dichotomous fertile organs within which sporangia were produced terminally on pinnately arranged ultimate branches (Walton, 1957; Smith, 1962).

The sporangia, approximately $3 \mathrm{~mm}$ long, dehisced by a longitudinal slit. Spherical, trilete spores are of variable size $(80-360 \mu \mathrm{m}$ in diameter) and are characterized by an enclosing, cutinized membrane. According to Smith (1962) "it is possible that ... the membrane is homologous with the air sac or saccus of some monosaccate spores and pollen ..." Because the spores fall into two distinct size classes, Smith endorses Walton's view that $P$. scotica represents an early stage in the evolution of heterospory. He believes that the intact spore (with saccus or "perine" present) can reasonably be "compared to a monosaccate type such as ... Remysporites B. and W., a genus whose only known species, $R$. magnificus (Horst) B. and W., is the pollen of a pteridosperm, Paracalathiops stachei Remy ..."

This arborescent plant whose stems are known to have exceeded $45 \mathrm{~cm}$ in diameter, produced massive, dense secondary wood of gymnospermous aspect. Pitting on the radial walls of tracheids is uniseriate to multiseriate circular-bordered, the tracheids adjacent to the metaxylem often uniseriate with elliptical, bordered pits (Smith, 1962); vascular rays are uniseriate and small ( $2-3$ cells high) in $P$. scotica, but sometimes biseriate and up to 15 cells high in $P$. buchiana.

Metaxylem encloses the pith, elliptical in transverse view. Protoxylem developed in the in ward regions of two adjacent "strands" along opposite, narrow sides of the pith. These pairs of strands divided in succession to form leaf traces, each consisting of two vascular bundles. Consequently, leaves were borme alternately and distichously. Unfortunately, nothing is known of the anatomy and morphology of vegetative leaves of lateral branch systems of Protopitys.

\section{ARCHAEOPTERIDALES}

This group is composed of genera with three-dimensional or bilaterally symmetrical (planated) lateral branch systems. The main axis of Svalbardia is often considered to bear lateral branches in a helical pattern (Carluccio et al., 1966; Andrews, 1970; Chaloner, 1972), but Hфeg's (1942) descriptions do not provide a clear picture of the branching pattern of this genus (Beck, 1971). Branching is helical in Actinoxylon (Matten, 1968) and bilateral opposite to alternate in Archaeopteris and Siderella. Actinopodium (Hфeg, 1942) is characterized by a transverse stelar configuration apparently identical with that of Archaeopteris, and its branching was probably also bilateral. 
Uitimate appendages (simple leaves) are dichotomously branched and finely divided in Sualbardia, Actinoxylon and some species of Archaeopteris. In other species of Archaeopteris and in Eddya they are broadly laminate. Leaves are arranged helically on the penultimate branches of Sualbardia, Actinoxylon, Archeopteris, and Siderella, and in the two latter genera, at least, they are decurrent on the axes that bear them. On the ultimate branches leaves are arranged helically in Svalbardia ( $\mathrm{H} \phi \mathrm{eg}, 1942)$, decussately in Actinoxylon, decussately and/or helically in Archaeopteris, and, apparently, bilaterally in Siderella.

Fertile structures are known only in Svalbardia and Archaeopteris. Hфeg (1942) noted that the fertile foliage of Sualbardia is apparently identical with that of Archaeopteris. No subsequent study has provided data which alter this evaluation. Fertile ultimate appendages of Archaeopteris, considered to be homologous with vegetative leaves, were borne typically in the basal parts of lateral branch systems that otherwise are vegetative. (Phillips et al. (1972) suggest that some lateral branch systems may be entirely fertile.) The branching pattern in fertile and vegetative regions is identical (Beck, 1971). Fertile ultimate appendages are apparently laminate structures, often dichotomously branched, distally. The linear components of which these appendages are comprised vary from narrowly (Andrews et al., 1965; Carluccio et al., 1966) to rather broadly laminate (Phillips et al., 1972). The more broadly laminate ones occur in regions of transition between fertile and vegetative parts of lateral branch systems, and do not, as far as we know, reflect the general condition in any species. Fertile appendages of $A$. fissilis bear small epidermal emergencies (Andrews et al.,1965).

Sporangia, which stand erect in one or more rows on adaxial surfaces of fertile ultimate appendages, vary in length from about 1.5-4.0 mm. Dehiscence was by a longitudinal slit.

Heterospory has been demonstrated in Archaeopteris latifolia (Arnold, 1939), A. cf. jacksoni (Pettitt, 1965), A. halliana and A. macilenta (Phillips et al., 1972). The spores, apparently identical in these species, have finely ornamented exines (megaspores "rugulate to incompletely reticulate" [Phillips et al., 1972] ) and trilete tetrad scars. Microspores range in diameter from $35-75 \mu \mathrm{m}$, and megaspores from 110-370 $\mu \mathrm{m}$ (Pettitt, 1970). Spore measurements of Phillips et al. (1972) are similar, but they observed megaspores, within sporangia, no smaller than $210 \mu \mathrm{m}$, and some dispersed megaspores as large as $460 \mu \mathrm{m}$ in diameter. Megaspores of Archaeopteris resemble the dispersed spore genus, Biharisporites Potonié.

With the exception of Callixylon and Eddya, the primary xylem of the "main" axis of all genera forms a multi-ribbed stele. The stele of Actinoxylon may be a protostele (Matten, 1968), but a pith characterizes Archaeopteris, Actinopodium and Siderella.

Callixylon, the large axes on which Archaeopteris macilenta (Beck, 1960a, b) and presumably other species were borne, is characterized by a large number of vascular bundles, apparently forming a eustele similar to that of the calamopityeans, lyginopterids and conifers (Beck, 1970, 1971). The 
details of morphology and the three-dimensional architecture of the Calli$x y$ lon stele, now being studied in this laboratory, are not yet fully understood.

Axes with ribbed steles in archaeopteridalean genera are probably main axes of lateral branch systems. It is possible that like Archaeopteris, all genera characterized by such axes represent lateral branch systems, or the more distal regions, of large plants whose main axes had an anatomy similar or identical to that of Callixylon. We already know that secondary wood of the Callixylon-type occurs in both some species of Archaeopteris and in Triloboxylon hallii (Scheckler and Banks, 1971a) as well as in Eddya. Callixylon, therefore, is a form genus (Beck, 1967).

Protoxylem is mesarch in the order. Leaf and branch traces of the main axes of lateral branch systems diverge radially from continuing strands or ribs, differing in detail from trace divergence in Callixylon in which, apparently, traces initially diverge from axial bundles along tangential planes as in the eusteles of seed plants.

There is evidence of secondary growth in Actinoxylon, Actinopodium, and Archaeopteris as well, of course, as in Callixylon and Eddya. In all of these genera tracheids of the compact secondary xylem bear multiseriate, circular-bordered pits (with the exception of Callixylon arnoldii [Beck, $1962 \mathrm{~b}$ ] in which pitting is predominantly uniseriate). The pits of Archaeopteris macilenta (Beck, 1960a, b), Eddya sullivanesis (Beck, 1967), and Callixylon occur in groups that are radially banded. Radial banding of grouped pits has not been observed in Actinoxylon and Actinopodium, but available data are so meagre that this possibility cannot be ruled out. My observations indicate that even in Callixylon, banding of pits is not characteristic of apparent secondary wood just outside the primary xylem. No specimens of Actinoxylon and Actinopodium described thus far have possessed more than a few layers of presumed secondary xylem tracheids. Secondary xylem is unknown in Siderella. The secondary wood of Calli$x y$ lon has been studied in great detail; readers wishing more information should refer to Beck (1970).

Archaeopteridales appear first in the late Middle Devonian (early Givetian), and extend into the Lower Mississippian (Tournaisian). The known ranges of individual genera are shown in Fig.2.

The following genera have been assigned to the order:

(1) Actinopodium Hoeg, 1942; (2) Actinoxylon Matten, 1968;

(3) Archaeopitys Scott et Jeffrey, 1914, (4) Archaeopteris Dawson, 1871 (see also Arnold, 1939; Kräusel and Weyland, 1941; Beck, 1960a, b, 1962, 19'i1; Andrews et al., 1965; Carluccio et al., 1966; (5) Eddya Beck, 1967; (6) Siderella Read, 1936 (see also Beck, 1971, pp.778-779);

(7) Svalbardia Hoeg, 1942 (see also Andrews, 1970; Chaloner, 1972).

The form genus Callixylon (Zalessky, 1911; Arnold, 1930a, 1970, Beck, 1967, 1970; Scheckler and Banks, 1971a) includes fossils that represent the stem of Archaeopteris macilenta (Beck, 1960a, b) and Eddya sullivanensis (Beck, 1967). 


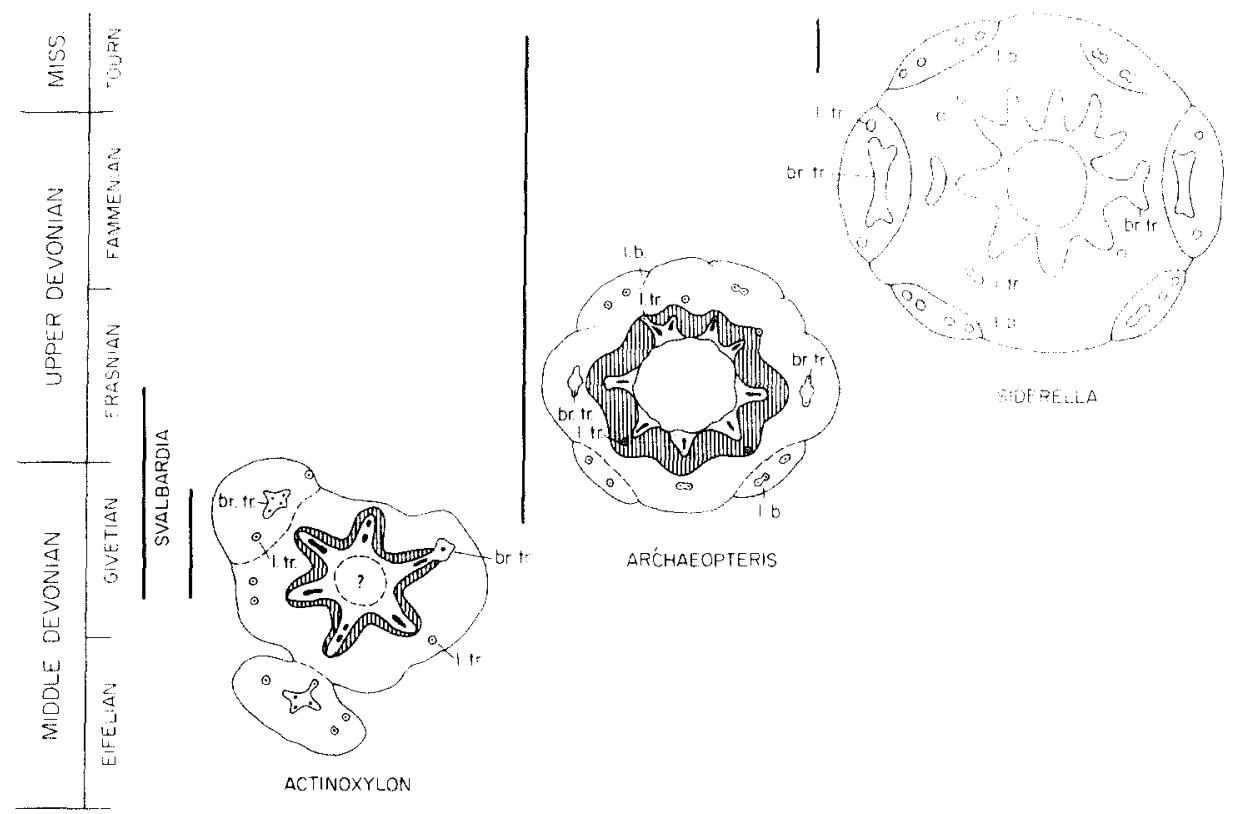

Fig. 2: Geologic ranges (heavy lines to left of names and diagrams) and morphologic features of some members of the Archaeopteridales. Some aspects of the primary and secondary xylem, branching patterns, and phyllotaxy are shown. Lined secondary xylem encloses unshaded metaxylem that contains black protoxylem strands. The smallest appendages containing one or more traces, terete in sectional view, are the basal parts of simple leaves. Note that the leaf bases of Archaeopteris and Siderella are decurrent on the axes that bore them. Genera are arranged from left to right in order of increasing levels of morphologic specialization. br.tr. = branch trace; $l . b .=$ leaf base; l. tr. = leaf trace.

Pitys was considered earlier to be a member of this group of genera, many of which I assigned to the order Pityales (Beck, 1960b). Since Long's (1963) presentation of evidence suggesting that Pitys was a pteridosperm, the name, Archaeopteridales (Arnold, 1930a) has gained general acceptance as the preferred ordinal name for this group of progymnosperms. While Long's evidence is highly suggestive, it does not provide proof that Pitys was a lyginopterid. Organic connection between Pitys stems and Lyginorachis papilio has not been demonstrated.

Archaeopitys eastmanii, the most poorly known member of the Archaeopteridales, was considered by Scott and Jeffrey (1914) to be similar to Pitys. Considering the fact that no other specimens fitting the description of this fossil have been discovered, and considering its source (the New Albany Shale), I believe that it might be a specimen of Callixylon. The type specimen should be carefully re-examined. 


\section{DISCUSSION}

In considering the Progymnospermopsida one is impressed both with the number of genera and their diversity of form and structure. It is equally apparent that the majority of genera fall into two major categories, the Aneurophytales and the Archaeopteridales.

As we consider each of these groups, several important questions arise: (1) Does the diversity reflect the evolution of many different genera, or merely developmental variation within a few genera? (2) Might not some of these genera represent the same group, but be maintained as separate taxa for lack of information?

\section{The effect of incomplete information}

Let us first consider that some genera are maintained apart for lack of proof of their common identities.

In the Aneurophytales, Rellimia, Aneurophyton, and Triloboxylon are remarkably similar, and their known vertical ranges are either overlapping or parallel. All are characterized by a basic helical branching pattern, and by dichotomous ultimate appendages. The primary vascular column of the main axis of each is a three-ribbed protostele. Secondary xylem is pycnoxylic, and characterized by multiseriate, circular-bordered pits (but additional evidence of such pits in Rellimia is needed). Rays are narrow and of variable height.

The fertile branch systems of Rellimia and Triloboxylon are planated and dichotomous with sporangia borne terminally on pinnately arranged (at least in Rellimia) ultimate appendages. Only a brief description of the fertile parts of Triloboxylon has been published (Scheckler and Banks, 1972) and reports on the morphology of Aneurophyton are conflicting (Leclercq and Bonamo, 1971). Such similarities suggest the possibility that Rellimia, Aneurophyton and Triloboxylon represent a single natural genus. Trilobo$x y$ lon is maintained as a separate taxon, however, because relatively little information on the morphology of its vegetative and fertile branch systems has been published. Conversely, very little is known about the internal structure of Rellimia. Additional information about either might clarify the relationship of these taxa. Aneurophyton needs to be fully restudied before its status as a genus can be further clarified.

Similar problems characterize the Archaeopteridales. Svalbardia can hardly be distinguished from Archaeopteris, the only distinction being helical to irregular branching in Svalbardia and sub-opposite to alternate distichous branching in Archaeopteris. Vegetative morphology of Actino$x y$ lon (in which fertile structures are unknown) is possibly indistinguishable from Sualbardia and differs from Archaeopteris only in branching pattern. Internal anatomy of Actinoxylon is similar to that of Archaeopteris and also to Actinopodium. Although poorly known, the structure of Actinopodium seems to be identical with that of main axes of lateral branch systems of 
Archaeopteris. Carluccio, et al. (1966) have suggested that Actinopodium might represent the structure of Svalbardia, a viewpoint that I strongly support. Actinopodium and Sualbardia polymorpha, both established by H申eg (1942), were collected from the same locality at different times and from beds of probably the same age. The probability that Actinopodium represents the structure of Svalbardia supports the view that Svalbardia and Archaeopteris are congeneric (Beck, 1971). Additional information about Sualbardia, Actinopodium and Actinoxylon is needed in order to draw final conclusions about the relationship of these forms with each other and with Archaeopteris.

\section{The possibility of ontogenetic variation}

The question of variation during development is more interesting and more difficult to resolve because it is essentially impossible to study more than a very small part of a large, extinct plant. The very fact, however, that the primary vascular columns of Cairoa and Proteokalon vary from three to four-ribbed provides evidence of ontogenetic variation. Could, for example, Triloboxylon (stele three-ribbed) simply represent distal regions of Tetraxylopteris or Proteokalon (steles four-ribbed)? The rather unusual, semiplanated arrangement of vegetative ultimate appendages of Proteokalon perhaps makes this less likely in this genus; but, in fact, we know very little about either Triloboxylon or Proteokalon which, as is true of most fossil genera, are based on only a few specimens of variable size and preservation.

It is well known (see Beck, 1967, 1969; Eggert, 1961, Namboodiri and Beck, 1968a) that stelar anatomy and phyllotaxy may vary from more proximal to more distal regions of determinate branch systems, or between essentially indeterminate lead shoots and relatively more determinate lateral branch systems. We must, therefore, consider whether such ontogenetic variation might account for the differences in anatomy and branching patterns.

Rellimia and Tetraxylopteris are nearly identical in known details except that branching is helical in the former and decussate in the latter, their protosteles being three-ribbed and four-ribbed, respectively. An additional minor difference is the single bifurcation of the fertile branch system in Rellimia compared with the double bifurcation in Tetraxylopteris. It is, at least, possible that these differences reflect developmental (ontogenetic) variation relating to position in the plant and/or response to environment. (For more detailed discussions of developmental variation in morphology see Beck, 1967, 1969.) Bonamo and Banks (1967) and Leclercq and Bonamo (1971) emphasize the remarkable similarity between Rellimia and Tetraxylopteris and consider the possibility of their identity.

Similarly, Actinoxylon and Archaeopteris might represent ontogenetically variant parts of a plant. Certainly, the presence or absence of a distinct pith, one of the possible (but not certain) differences between these genera might be a variation of this kind, the smaller axes being protostelic, the larger 
medullated. Even the difference in branching pattern might reflect ontogenetic variation. We do not know that the main axis of Actinoxylon (Fig.2) and the main axis of an Archaeopteris lateral branch system with which it is here compared are of equivalent order. The main axis of Actinoxylon might represent an axis that, in a young specimen or a distal region of Archaeopteris, bore lateral branch systems. At different times during the development of a plant equivalent axes might have had different internal anatomy. If the main axis of Actinoxylon were equivalent to such a stem, the helical pattern of branching would not be unexpected. Is it not possible that the helical/to irregular branching of Sualbardia might be accounted for in the same way?

When one considers this analysis and the strong probability that Actinopodium is identical with the structure of the main axis of Archaeopteris lateral branch systems, the conclusion that Svalbardia, Actinopodium, Actinoxylon and Archaeopteris might represent a single natural genus is inescapable, and parallels that regarding the possible identity of Rellimia, Triloboxylon and Tetraxylopteris.

I have previously provided a detailed rationale for the possibility that Eddya and Archaeopteris are different developmental stages of the same plant, Eddya being a young sporophyte of Archaeopteris (Beck, 1967).

These suggestions and the preceeding analyses are, of course, highly speculative, but they point to an important fact: We know relatively very little about the progymnosperms. This dilemma is common to paleobotany and related directly to the fact that plants are basically indeterminate in growth and that one is never able to study more than a small part of a single large plant.

\section{Evolutionary change through time}

I must emphasize again that these suggestions are highly speculative. Whereas it is clear that some of the diversity within Progymnospermopsida is probably the result of ontogenetic variation, a larger part of it is very likely the result of evolution through time. Indeed, one could argue that the major progymnosperm genera form a single continuum of evolutionary variation. The current state of our knowledge suggests, however, that some major taxonomic diversification had occurred within the group, and that at least two lines of evolution are represented.

In the Aneurophytales, Rellimia seems to have been a dominant group during mid-Devonian and Tetraxylopteris during late Devonian times. The remarkable morphological similarity between these genera suggests a very close genetic relationship. These homosporous genera even produced identical spores (Rhabdosporites langii, of the sporae dispersae) (Leclercq and Bonamo, 1971). Their differences may represent "straight line" evolutionary change through time, with the decussate branching pattern and fourribbed stele of Tetraxylopteris representing an evolutionary advance over the helical branching and three-ribbed stele of Rellimia. Leclercq and Bonamo (1971) have suggested that the more complex fertile "organ" of 
Tetraxylopteris is also an evolutionary specialization.

I believe that Protopitys which lived during early Mississippian times (although now assigned to a different order) may have been a still more highly specialized member of this same line of evolution. The alternate and distichous branching in this genus could have evolved from the decussate branching of Tetraxylopteris. It should be emphasized, furthermore, that entire Protopitys plants might not have been characterized by distichous branching. Unfortunately we know nothing of the leaves or vegetative branching systems of this plant. On the other hand, its secondary wood was similar to that of Tetraxylopteris and its fructifications and saccate spores remarkably similar, if not identical. As noted earlier, the presence of two fairly distinct size classes - 75 to about $200 \mu \mathrm{m}$ and about 200 to $355 \mu \mathrm{m}-$ suggested to Smith (1962), as it had earlier to Walton (1957), the possibility that this variation in spore size reflects an intermediate stage in the evolution of heterospory. It is, indeed, interesting that the range of spore diameter in Tetraxylopteris $\left(73^{-} 176 \mu \mathrm{m}\right)$ corresponds approximately to the smaller class of spores of Protopitys.

Information on the morphology and anatomy of lateral branch systems and leaves of Protopitys will clarify its phylogenetic position and might show it to be a Carboniferous member of the Aneurophytales. (It is intriguing, though entirely speculative, to suggest that Stauroxylon (Galtier, 1970) might represent a part of the lateral branch systems of Protopitys.) In the meantime Protopitys must remain in the Protopityales.

Very little is known about Cairoa, and its phylogenetic position is unclear. Proteokalon is also relatively poorly understood, but is characterized by two features of considerable interest. As in the case of Cairoa, it exhibits both four- and three-ribbed protosteles. In Proteokalon, the three-ribbed stele, T-shaped in transverse configuration, occurs in leaf-bearing axes. The most unusual feature of this plant is the arrangement of leaves along the axis in adaxial pairs that alternate with single abaxial leaves (Scheckler and Banks, $1971 \mathrm{~b}$ ), producing a sort of bilateral symmetry (Fig.1).

The helical branching and phyllotaxy of Triloboxylon (also of Rellimia and possibly Aneurophyton), the decussate branching and phyllotaxy of Tetraxylopteris and the decussate branching and semi-planated leaf arrangement of Proteokalon and the associated changes in stelar form provide another example of possible evolutionary specialization through time, and as Banks and Scheckler point out, may illustrate stages in the evolution of a planated compound leaf from a more primitive system of simple leaves exhibiting helical phylotaxy.

In the aneurophytes helical branching was probably primitive, decussate and distichous derived; the latter type had evolved in only fertile branch systems. If, as is quite possible, the presumed stems of Protopitys (as described by Walton, 1957, and Smith, 1962) are found to be axes of lateral branch systems and the presumed leaf traces, branch traces instead, we may extend this trend in vegetative branching patterns from helical through decussate to distichous (bilateral). Distichous (planated) branching in a 
lateral branch system (as in Archaeopteris) is clearly adaptive; it would seem unlikely as the pattern of main axes of a large plant (as has been presumed to be the case in Protopitys).

A similar, clear-cut succession of changes in branching pattern, leaf arrangement, and anatomy can be described in the archaeopteridalean genera, Actinoxylon, Archaeopteris and Siderella (Fig.2). As in the aneurophytes these changes may be time-correlated, the known range of Actino$x y$ lon being restricted to the late Middle Devonian (Givetian), Archaeopteris extending from late Middle Devonian into early Mississippian (Tournasian) and Siderella being known only from the early Mississippian. The presumed trend in branching patterns is from helical (Actinoxylon and possibly Svalbardia) to sub-opposite or alternate and distichous in Archaeopteris and Siderella. In phyllotaxy, the changes seem to have been from helical or decussate in Actinoxylon and Archaeopteris to alternate and bilateral (planated) in Siderella. These apparent trends, like those among aneurophytes, not only reflect different levels of evolutionary specialization of the several genera (Figs.1, 2), but also support the contention that compound leaves may have arisen through planation of three-dimensional lateral branching systems (Matten, 1968; Beck, 1970). It is important to understand, however, that Archaeopteris did not bear compound leaves. It bore planated lateral branch systems bearing helically arranged simple leaves (Carluccio et al., 1966; Beck, 1971) very similar to those of some modern conifers.

Unfortunately we do not know whether Siderella bore compound leaves or planated lateral branch systems bearing simple leaves. When we learn more about Siderella and other possible descendants of Archaeopteris such as Rhacopteris, Palaeopteridium, Saaropteris, Noeggerathia, etc., and Protopitys and other possible descendants of the aneurophytes, we may be able to determine positively whether the lateral branch systems of the progymnosperms do, in fact, represent intermediate stages in the evolution of compound leaves.

\section{THE PHYLOGENETIC POSITION OF THE PROGYMNOSPERMS}

The two major groups of progymnosperms, while apparently distinct, are tied together by some important common characteristics. There are, of course, the general characters of the class; but in addition, some or all members of both groups bore finely and dichotomously divided simple leaves, and produced ribbed steles. At least one member of each group produced secondary wood containing ray tracheids and axial tracheids bearing grouped and banded circular-bordered pits, characters that are known to occur elsewhere in the plant kingdom only in certain conifers.

When one considers all of the evidence, the Aneurophytales has clearly the more primitive aspect of the two orders. It extends farthest back in the geologic column. The Archaeopteridales might have diverged from a primitive member of this group (Beck, 1966); but it seems equally probable that 
the two orders diverged from an unknown common ancestor.

In several other papers (Beck, 1960b, 1966, 1971) I have developed a rationale for the view that the gymnosperms evolved from the Progymnospermopsida. Since my original proposal in 1960, a large body of evidence has accumulated through the efforts of many workers. Studies in my laboratory (Beck, 1971) and by Harlan Banks and his students (Carluccio et al., 1966) of the anatomy and morphology of lateral branch systems have demonstrated beyond any doubt that they are planate, probably determinate, and bear helically arranged, simple leaves with decurrent, and adherent leaf bases. In other words, they have all of the characteristics of lateral branch systems of some members of the coniferales.

Analyses and reinterpretations of stelar morphology of primitive and extant gymnosperms by my students and me (Namboodiri and Beck, 1968a, b, c; Beck, 1970; Devadas and Beck, 1972; Blanc-Louvel, 1966; Galtier, 1970, 1973; and Slade, 1971) have clarified the three-dimensional morphology of the stele of seed plants and demonstrate its similarity to the stele of the progymnosperms. In both progymnosperms and gymnosperms, whether basically protostelic (including medullated protosteles) or eustelic, leaf traces diverge directly from longitudinal ribs or discrete vascular bundles. Namboodiri and Beck (1968c) and Beck (1970) have shown how the eustele may have been derived directly from the ribbed protostele. There is no morphologic discrepancy between the organization of progymnosperms, primitive gymnosperms and extant gymnosperms. This clarification of stelar morphology further strongly supports the contention that gymnosperms are descendants of progymnosperms.

Further support for this view comes from the many details of anatomy and morphology of aneurophytes, discerned largely through the studies of Harlan Banks and his students at Cornell, Patricia Bonamo of Binghamton, and Suzanne Leclercq of Liège. For example, the discovery of ray tracheids and grouped, radially banded, bordered pits in the secondary wood of Triloboxylon hallii by Scheckler and Banks (1971) not only supports the assumed close relationship of Aneurophytales and Archaeopteridales, but, importantly, also supports the proposed relationship of progymnosperms with gymnosperms, the only other major group in which these characters are known to occur.

The anastomosing strands of cortical sclerenchyma in aneurophytes strongly resemble similar structures in the calamopityeans and lyginopterid gymnosperms.

Secondary phloem characterizes all three orders of progymnosperms. In the opinion of Scheckler and Banks (1971a) this characteristic is "perhaps the strongest evidence for the gymnospermous affinity of the progymnosperms", because as they further point out, "cambial activity does not produce any secondary phloem in woody ferns, lycopods, and calamites ..." The aneurophytes produced rather distinctive secondary phloem containing scattered strands or rows of thick-walled fibers (Beck, 1975, Scheckler and Banks, 1971a, b). The secondary phloem of Callixylon 
(large axes of Archaeopteris) is parenchymatous, lacking fibers, and characterized by well-defined rays (Arnold, 1930b). The secondary phloem of Protopitys is poorly known, but a brief report by Walton (1969) suggests that it was more like that of Callixylon than that of the aneurophytes.

The generally gymnospermous features of the secondary xylem of progymnosperms, and, especially, the remarkably detailed similarity between the wood of Callixylon and members of the Coniferales has been recently documented (Beck, 1970) and will not be discussed again here.

The production of periderm in several progymnosperms is another feature believed to support their close relationship with gymnosperms (Scheckler and Banks, 1972b).

A recent, significant development that tends to relate the progymnosperms and gymnosperms is the discovery of 'pseudosaccate' spores (Rhabodosporites of the Sporae dispersae) in two aneurophytes, Tetraxylopteris (Bonamo and Banks, 1967) and Rellimia (Leclercq and Bonamo, 1971), and similar spores (compared with the monosaccate pteridosperm pollen grain, Remysporites) in Protopitys (Smith, 1962). The spores of both the aneurophyte genera and Protopitys are spherical and consist of a corpus enclosed by a thin, bladder-like membrane attached proximally in the region of the trilete mark. This type of spore may have been a precursor of monosaccate pteridosperm or cordaite pollen grains in which the saccus was attached at both proximal and distal ends and in which had evolved a clear proximo-distal differentiation. Millay and Taylor (1974) have described two new pollen genera, Sullisaccites and Felixipollenites, that they consider to be related taxonomically to the Cordaitales. Whereas Felixipollenites is believed to be the more primitive, they are, together, intermediate in morphology between a pseudo-saccate spore such as Rhabdosporites and a relatively highly specialized saccate pteridosperm pollen grain such as Vesicaspora (pollen of Callistophyton) or a cordaitean grain such as Florinites (pollen of Cordaites). Indeed, Millay and Taylor believe that "spores of Tetraxylopteris . . possess most of the features that would be required of the ancestor of Felixipollenites".

Phillips et al. (1972) have contributed to a better understanding of the morphology of fertile ultimate appendages of Archaeopteris. They have shown that sporangia of $A$. halliana occur extensively over the adaxial surface of thrice-dichotomized appendages, extending to but not beyond the third dichotomy. They suggest that such appendages might have evolved into cupulate structures like those of the Upper Devonian fructification, Archaeosperma Pettitt et Beck, 1968, in which seeds were enclosed. Pettitt and Beck (1968) postulated that "evolutionary reduction of an Archaeopteris fertile ultimate branch and its appendages could result in several megasporangia, each surrounded by an integument derived either from sterile sporangia . . . or from the laminar fertile leaves, borne in cupules derived from the basal vegetative leaves."

There is no evidence that any species of Archaeopteris produced seeds or that those of any primitive gymnosperm were derived directly from 
Archaeopteris fructifications. Morphological similarities of parts of these fructifications to primitive seed cupules and integuments are, however, consistent with the belief that some progymnosperms might have been precursors of some gymnosperms.

A gradually growing fund of data tends to support the hypothesis that gymnosperms evolved from the Progymnospermopsida. In 1966 I suggested that the lyginopterid Pteridosperms probably evolved from the aneurophytes. This view was based then, and supported with more detail later (Beck, 1970), on the similarity between stelar morphology of the aneurophytes and the calamopityeans and the apparently closely related lyginopterids (Galtier, 1974). The Archaeopteridales seem to be the most likely source of the coniferophytic gymnosperms, this view based largely on the remarkable resemblance between the secondary wood (Callixylon) and lateral branch systems of Archaeopteris and those of Coniferales (see Beck, 1970, 1971).

Although aneurophytes and archaeopterids at present seem to represent distinct, clearly defined lines of evolution, it is only prudent to recognize that the progymnosperms may comprise only one, branching line of evolution from which the two main lines of evolution among gymnosperms originated. If so, the gymnosperms could be considered to be of monophyletic origin as has been suggested by Scheckler and Banks (1971a).

Much has been written about the probable seed-plant descendants of the progymnosperms, but almost nothing about possible pteridophytic descendants. Is it not possible that some progymnosperms persisted well into and, perhaps, through the Carboniferous? Archaeopteris and Siderella occur in the early Mississippian, as does Protopitys. In strata of comparable and younger age, in both North America and Europe, there occur also a large number of vegetative foliage genera such as Rhacopteris, Sphenopterididium, Triphyllopteris, Adiantites, Palaeopteridium, and Saaropteris, of unknown taxonomic affinity. Some of these may represent ferns, others primitive gymnosperms (as has been shown recently to be true of Rhodea [Jennings, 1974]). Still others might be progymnosperms. Palaeopteridium and Saaropteris have been grouped with Noeggerathia on the basis of similarity of leaf (or leaflet) form (Hirmer, in Hirmer and Guthörl, 1940). The fructifications of Noeggerathia are similar to those of Archaeopteris as is, possibly, the arrangement of vegetative leaves. (The latter possibility is suggested by my recent unpublished re-interpretation based on published photographs.) This very preliminary evidence and analysis suggests at least the possibility that Noeggerathia is a Pennsylvanian progymnosperm. Further, intensive study of this genus is planned. This and studies of other possible Carboniferous progymnosperms and primitive gymnosperm descendants, with continuing investigations of Devonian progymnosperms, will further clarify the phylogenetic relationship between the progymnosperms and the gymnosperms. 


\section{REFERENCES}

Andrews, H. N., 1970. Familles primitives d'affinités incertaines. In: E. Boureau (Editor), Traité de Paléobotanique, Tome IV, Fasc. 1, Filicophyta. Masson, Paris, pp. 19-31.

Andrews, H. N. and Phillips, T. L., 1968. Rhacophyton from the Upper Devonian of West Virginia. J. Linn. Soc. (Bot)., 61:37-64.

Andrews, H. N., Phillips, T. L. and Radforth, N. W., 1965. Paleobotanical studies in arctic Canada. I. Archaeopteris from Ellesmere Island. Can. J. Bot., 43: 545-556.

Andrews, H. N., Gensel, P. G. and Forbes, W. H., 1974. An apparently heterosporous plant from the Middle Devonian of New Brunswick. Palaeontology, 17: 387-408.

Arnold, C. A., 1930a. The genus Callixylon from the Upper Devonian of central and western New York. Pap. Mich. Acad. Sci., 11: 1-50.

Arnold, C. A., 1930b. Bark structure of Callixylon. Bot. Gaz., 90: 427-431.

Arnold, C. A., 1939. Observations on fossil plants from the Devonian of eastern North America. IV. Plant remains from the Catskill Delta deposits of northern Pennsylvania and southern New York. Contrib. Mus. Paleontol. Univ. Mich., 5: 271-313.

Arnold, C. A., 1970. Genre Callixylon Zalessky, 1911. In: E. Boureau (Editor), Traité de Paléobotanique, Tome IV, Fasc. 1, Filicophyta. Masson, Paris, pp. 435-444.

Beck, C. B., 1957. Tetraxylopteris schmidtii gen. et sp. nov., a probable pteridosperm precursor from the Devonian of New York. Am. J. Bot., 44: 350-367.

Beck, C. B., 1960a. Connection between Archaeopteris and Callixylon. Science, 131: $1524-1525$.

Beck, C. B., 1960b. The identity of Archaeopteris and Callixylon. Brittonia, 12: $351-368$.

Beck, C. B., 1962a. Reconstructions of Archaeopteris, and further consideration of its phylogenetic position. Am. J. Bot., 49: 373-382.

Beck, C. B., 1962b. Plants of the New Albany Shale. II. Calixylon arnoldii sp. nov. Brittonia, 14: 322-327.

Beck, C. B., 1964. The woody, fern-like trees of the Devonian. Mem. Torrey Bot. Club, 21: $26-37$.

Beck, C. B., 1966. On the origin of gymnosperms. Taxon, 15: 337-339.

Beck, C. B., 1967. Eddya sullivanensis, gen. et sp. nov., a plant of gymnospermic morphology from the Upper Devonian of New York. Palaeontographica, B., 121: 1-22.

Beck, C. B., 1969. Problems of generic delimitation in paleobotany. Proc. N. A. Paleontol. Conv., Part C, 173-193.

Beck, C. B., 1970. The appearance of gymnospermous structure. Bot. Rev. Camb. Philos. Soc., 45: 379- 400 .

Beck, C. B., 1971. On the anatomy and morphology of lateral branch systems of Archaeopteris. Am. J. Bot., 58: 758-784.

Blanc-Louvel, C., 1966. Etude anatomique comparée des tiges et des pétioles d'une ptéridosperme du Carbonifère du genre Lyginopteris Potonié. Mém. Mus. Nat. Hist. Nat. (Paris), Sér. C., 18: 1-103.

Bonamo, P. M. and Banks, H. P., 1967. Tetraxylopteris schmidtii: its fertile parts and its relationships within the Aneurophytales. Am. J. Bot., 54: 755-768.

Carluccio, L. C., Hueber, F. M. and Banks, H. P., 1966. Archaeopteris macilenta, anatomy and morphology of its frond. Am. J. Bot., 53(7): 719-730.

Chaloner, W. G., 1972. Devonian plants from Fair Isle, Scotland. Rev. Palaeobot. Palynol., 14: 49-61.

Dawson, J. W., 1871. The fossil plants of the Devonian and Upper Silurian formation of Canada. Geol. Surv. Can., 92 pp.

Devadas, C. and Beck, C. B., 1972. Comparative morphology of the primary vascular systems in some species of Rosaceae and Leguminosae. Am. J. Bot., 59: 557-567.

Eggert, D. A., 1961. The ontogeny of Carboniferous arborescent Lycopsida. Palaeontographica, B., 108: 43-92. 
Galtier, J., 1970. Recherches sur les végetaux à structure conservée du Carbonifère inférieur français. Paleobiol. Cont. Montp., 1(4): 221 pp.

Galtier, J., 1973. Remarques sur l'organization et la signification phylogénétique de la stèle des Calamopityacées. C.R. Acad. Sci., Paris, 276: 2147-2150.

Galtier, J., 1974. Sur l'organisation de la fronde des Calamopitys, Ptéridospermales probables du Carbonifère inférieur. C.R. Acad. Sci., Paris, 279: 975-978.

Gensel, P. G., 1973. A new plant from the lower Mississippian of southwestern Virginia, Palaeontographica, B., 142: 137-153.

Hirmer, M. and Guthörl, P., 1940. Die Karbon-Flora des Saargebietes. Abt. 3: Filicales und Verwand te (Noeggerathiineae; Rhacopteris). Palaeontographica, Bot. Suppl., 9:1-60.

Hфeg, O. A., 1942. The Downtonian and Devonian flora of Spitzbergen. Skrifter Norges Svalbard og-Ishavs-Unders $\phi$ kelser, 83:228 pp.

Jennings, J. K., 1974. The morphology and relationship of Rhodea, Telangium, Telangiopsis, and Heterangium. Dissertation, University of Michigan, Ann Arbor, Mich., 83 pp.

Kräusel, R. and Weyland, H., 1923. Beiträge zur Kenntnis der Devonflora. 1. Senckenbergiana, 5: 154-184.

Kräusel, R. and Weyland, H., 1926. Beiträge zur Kenntnis der Devonflora. II. Abh. Senckenberg. Naturforsch. Ges., 40: 115-155.

Kräusel, R. and Weyland, H., 1929. Beiträge zur Kenntnis der Devonflora. III. Abh. Senckenberg. Naturforsch. Ges., 41: 317-359.

Kräusel, R. and Weyland, H., 1941. Pflanzenreste aus dem Devon von Nord-Amerika. II. Die Oberdevonischen Floren von Elkins, West-Virginien, und Perry, Maine, mit Berücksichtigung einiger Stücke von der Chaleur-Bai, Canada. Palaeontographica, B., $86: 3-78$.

Leclercq, S., 1940. Contribution à l'étude de la flore du Dévonien de Belgique. Acad. R. Belg., 12: 1-65.

Leclercq, S. and Bonamo, P. M., 1971. A study of the fructification of Milleria (Protopteridium) thomsonii Lang from the Middle Devonian of Belgium. Palaeontographica, B., 136: 83-114.

Leclercq, S. and Bonamo, P. M., 1973. Rellimia thomsonii a new name for Milleria (Protopteridium) thomsonii Lang, 1926 emend. Leclercq and Bonamo 1971. Taxon, 22: 435-437.

Long, A. G., 1963. Some specimens of Lyginorachis papilio Kidston associated with stems of Pitys. Trans. R. Soc. Edinb., 65: 211-224.

Matten, L. C., 1968. Actinoxylon banksii gen. et sp. nov., a progymnosperm from the Middle Devonian of New York. Am. J. Bot,, 55: 773-782

Matten, L. C., 1973. The Cairo flora (Givetian) from eastern New York. I. Reimannia, terete axes, and Cairoa lamanekii gen. et sp. n. Am. J. Bot., 60:619-630.

Matten, L. C. and Banks, H. P., 1966. Triloboxylon ashlandicum gen. et sp. nov. from the Upper Devonian of New York. Am. J. Bot., 53: 1020-1028.

Matten, L. C. and Banks, H. P., 1967. Relationship between the Devonian progymnosperm genera Sphenoxylon and Tetraxylopteris. Bull. Torrey Bot. Club., 94:321-333.

Millay, M. A. and Taylor, T. N., 1974. Morphological studies of Paleozoic saccate pollen. Palaeontographica, B., 147: 75-99.

Namboodiri, K. K. and Beck, C. B., 1968a. A comparative study of the primary vascular system of conifers. I. Genera with helical phyllotaxis. Am. J. Bot., 55: 447-457.

Namboodiri, K. K. and Beck, C. B., 1968b. A comparative study of the primary vascular system of conifers. II. Genera with opposite and whorled phyllotaxis. Am. J. Bot., 55: $458-463$.

Namboodiri, K. K. and Beck, C. B., 1968c. A comparative study of the primary vascular system of conifers. III. Stelar evolution in gymnosperms. Am. J. Bot., 55: 464-472.

Pettitt, J. M., 1965. Two heterosporous plants from the Upper Devonian of North America. Bull. Br. Mus. Nat. Hist. (Geol.), 10: 83-92. 
Pettitt, J. M., 1970. Heterospory and the origin of the seed babit. Biol. Rev. Camb. Philos. Soc., 45: 401-415.

Pettitt, J. M. and Beck, C. B., 1968. Archaeosperma arnoldii-a cupulate seed from the Upper Devonian of North America. Contr. Mus. Paleontol. Univ. Mich., 22: 139-154.

Phillips, T. L., Andrews, H. N. and Gensel, P. G., 1972. Two heterosporous species of Archaeopteris from the Upper Devonian of West Virginia. Palaeontographica, B., 139: 47-71.

Potonié, R., 1967. Versuch der Einordnung der fossilen Sporae dispersae in das phylogenetische System der Pflanzenfamilien. Geol. Land. Nordrhein-Westfalen, Krefeld, 1761: $310 \mathrm{pp}$.

Read, C. B., 1936. A Devonian flora from Kentucky. Paleontology, 10: 215-227.

Scheckler, S. E. and Banks, H. P., 1971a. Anatomy and relationships of some Devonian progymnosperms from New York. Am. J. Bot., 58: 737-751.

Scheckler, S. E. and Banks, H. P., 1971b. Proteokalon a new genus of progymnosperms from the Devonian of New York State and its bearing on phylogenetic trends in the group. Am. J. Bot., 58: 874-884.

Scheckler, S. E. and Banks, H. P., 1972a. New data on fertile branches, roots, and growth in Aneurophytales. Am. J. Bot., 59:663 (abstract).

Scheckler, S. E. and Banks, H. P., 1972b. Periderm in some Devonian plants. Adv. Plant Morphol., 58-64.

Schweitzer, H., 1968. Pflanzenreste aus dem Devon Nord-Westspitzbergens. Palaeontographica, B., 123: 43-75.

Scott, D. H. and Jeffrey, E. C., 1914. On fossil plants showing structure, from the base of the Waverley Shale of Kentucky. Philos. Trans. R. Soc. London, 205B: 315-373.

Slade, B. F., 1971. Stelar evolution in vascular plants. New Phytol., 70: 879-884.

Smith, P. L., 1962. Three fructifications from the Scottish Lower Carboniferous. Palaeontology, 5: 225-237.

Streel, M., 1964. Une association des spores du Givétien inférieur de la Vesdre, a Goé (Belgique). Ann. Soc. Géol. Belg., 87: 1-30.

Walton, J., 1957. On Protopitys (Göppert): with a description of a fertile specimen Protopitys scotica sp. nov. from the Calciferous Sandstone series of Dunbartonshire. Trans. R. Soc. Edinb., 63: 333-340.

Walton, J., 1969. On the structure of a silicified stem of Protopitys and roots associated with it from the Carboniferous (Mississippian) of Yorkshire, England. Am. J. Bot., 56: 808-813.

Zalessky, M. D., 1911. Étude sur l'anatomie du Dadoxylon tchihatcheffi Goeppert. Mém. Com. Géol. Russe, N. S., 68: 18-29. 